\title{
Nitrite dynamics in the open ocean - clues from seasonal and diurnal variations
}

\author{
Efrat Meeder ${ }^{1,2, *}$, Katherine R. M. Mackey ${ }^{3}$, Adina Paytan ${ }^{3}$, Yeala Shaked ${ }^{1,2}$, \\ David Iluz ${ }^{4,5}$, Noga Stambler ${ }^{4}$, Tanya Rivlin ${ }^{2}$, Anton F. Post ${ }^{2}$, Boaz Lazar ${ }^{1,2}$ \\ ${ }^{1}$ Ferdy and Nadine Hermann Institute of Earth Sciences, Hebrew University, Edmond J. Safra Campus, Jerusalem 91904, \\ Israel \\ ${ }^{2}$ Interuniversity Institute for Marine Sciences Coral Beach, PO Box 469, 88103 Eilat, Israel \\ ${ }^{3}$ Institute of Marine Science, University of California Santa Cruz, Santa Cruz, California 95064, USA \\ ${ }^{4}$ Mina \& Everard Goodman Faculty of Life Sciences, and ${ }^{5}$ Department of Geography and Environment, Bar-Ilan University, \\ Ramat-Gan 52900, Israel
}

\begin{abstract}
Two alternative mechanisms are suggested for nitrite accumulation in the oxygenated oligotrophic water column: (1) excretion by phytoplankton or (2) microbial oxidation of ammonium (nitrification). This study assessed the role of these 2 mechanisms, based on seasonal and high-resolution diurnal depth profiles of the dissolved inorganic nitrogen (DIN) species (nitrite, ammonium, nitrate) and chlorophyll $a$ in the Gulf of Aqaba, Red Sea. Both mechanisms operated in the water column, but in different seasons; nitrification was the prime process responsible for nitrite accumulation during the stratified summer season and phytoplankton nitrite excretion operated during winter mixing. At the onset of summer stratification two $\mathrm{N}$ peaks developed below the photic zone, an ammonium maximum (AM) and below it the primary nitrite maximum (PNM). Both peaks were located at a depth range where phytoplankton are thought to be inactive and not excreting nitrite. During summer stratification, the water column deep chlorophyll maximum (DCM), AM, PNM and the nitracline were ordered by a downward increase in N oxidation state similar to the temporal order of the N-species during nitrification. This similarity, together with the diurnal stability of the PNM and its co-existence with oscillating chlorophyll profiles above the DCM, is consistent with nitrification as the key process forming the PNM. We suggest that transport and reaction control the vertical order and separation of $\mathrm{N}$-species in the water column. The ratios between the rate constants for ammonification, ammonium oxidation, nitrite oxidation and nitrate assimilation were estimated by a simple box model to be 1:3:1.5:0.15, respectively. These field estimates are similar to the ratios between the rate constants measured in laboratory experiments.
\end{abstract}

KEY WORDS: Nitrite $\cdot$ Nitrification $\cdot$ Nitrite excretion $\cdot$ Primary nitrite maximum $\cdot$ Ammonium maximum $\cdot$ Gulf of Aqaba $\cdot$ Red Sea

Resale or republication not permitted without written consent of the publisher

\section{INTRODUCTION}

Nitrite is a common intermediate in several redox processes of the marine nitrogen cycle, but its turnover is fast and hence it rarely accumulates in the oxygenated water column. There are 2 exceptions to this: (1) the primary nitrite maximum (PNM), a sharp peak of nitrite (concentration range of 0.01 to
$0.4 \mu \mathrm{mol} \mathrm{l}^{-1}$ ) at the base of the photic zone in stratified water bodies, decreasing to virtually zero on both sides of the peak (Lomas \& Lipschultz 2006), and (2) the accumulation of nitrite below the photic zone during periods of convective mixing (Al-Qutob et al. 2002, Lomas \& Lipschultz 2006). Recently, high nitrite concentrations were also reported from the oxygenated transition middle shelf zone in the 
Bering Sea (Mordy et al. 2010). Two processes are suggested to explain this nitrite accumulation: (1) excretion of nitrite by phytoplankton and bacteria due to incomplete reduction of nitrate (Wada \& Hattori 1971, Kiefer et al. 1976, Collos 1998), and (2) uncoupling between ammonium oxidation to nitrite and subsequent nitrite oxidation (nitrification) by bacteria and archaea (Brandhorst 1959, Francis et al. 2005, Mordy et al. 2010).

The common view is that the 2 nitrification steps, ammonium oxidation and nitrite oxidation, are separated by the light intensity, which decreases exponentially with depth. The vertical separation is hypothesized to stem either from differential photoinhibition (Olson 1981) or differential recovery of the activity of the nitrifiers following photoinhibition (Guerrero \& Jones 1996b). These hypotheses are based on the finding that light inhibits the activity of nitrifying bacteria (Hooper \& Terry 1974, Olson 1981, Guerrero \& Jones 1996a). Yet, nitrifying bacteria are rather uniformly distributed in the water column (Ward 2008), and they are also present in the photic zone (Horrigan et al. 1981, Guerrero \& Jones 1996a). Hence, if phytoplankton growth responses are faster than the rate of change of the daily light cycle, the shape of the nitrite profile is expected to fluctuate diurnally due to the effect of light intensity on ammonium oxidation and phytoplankton excretion. The diel cycle of the PNM has been investigated in only a few studies and at low temporal resolution (French et al. 1983, Al-Qutob et al. 2002). In this study we use the diel cycle of nitrite and chlorophyll profiles to shed light on the mechanism responsible for nitrite accumulation at our study site.

In addition to the effect of light, the rate of nitrification at different depths in the water column is also determined by substrate availability. The tight relationship between the vertical locations of the deep chlorophyll maximum (DCM) and the PNM provides a clue to the role of phytoplankton in providing the needed substrate for nitrification. The vertical distances between the DCM, PNM and the nitracline seem to be consistent at various sites (Kiefer et al. 1976, Dore \& Karl 1996b, Adornato et al. 2005), but much less is known about the spatial relationships between the PNM and the narrow ammonium maximum (AM) located several meters above it (Collos \& Slawyk 1983, Saino et al. 1983, Brzezinski 1988, Woodward \& Rees 2001). Unlike the PNM, the AM is elusive and does not appear at many oceanographic stations (Collos \& Slawyk 1983). The AM is possibly present but not always observed either due to its narrow peak, which may not get sampled depending on the sampling depth intervals for a given profile, or its extremely low concentrations in oligotrophic waters.

Nitrification rates in the open ocean (measured mainly as ammonium oxidation rates) range from several nmol $\mathrm{l}^{-1} \mathrm{~d}^{-1}$ to several hundred nmol l-1 $\mathrm{d}^{-1}$ (Ward \& Zafiriou 1988, Dore \& Karl 1996b, Sutka et al. 2004, Mackey et al. 2011). The highest rates of ammonium oxidation are associated with the lower region of the photic zone (Ward 2008). Reports on nitrite oxidation rates are limited due to analytical difficulties in determination, but published data are usually comparable to ammonium oxidation rates (Ward 2008). Recently, ammonium and nitrite oxidation rates in the Atlantic Gyre were estimated to be 1 to $10 \mathrm{nmol}^{-1} \mathrm{~d}^{-1}$ and 1 to $30 \mathrm{nmol} \mathrm{l}^{-1} \mathrm{~d}^{-1}$, respectively (Clark et al. 2008).

Studies in oxygenated oligotrophic ecosystems in general (summarized in the review on different aspects of nitrite formation mechanisms by Lomas \& Lipschultz 2006) and in the Red Sea in particular (AlQutob et al. 2002) ascribe nitrite accumulation to just one of the 2 mentioned mechanisms. It is possible that both processes take place in the same oceanic region but operate in different hydrographic seasons (Dore \& Karl 1996a, Mackey et al. 2011).

This study used the unique oceanographic features of the Gulf of Aqaba (GOA), Red Sea, to examine the mechanisms and rates controlling nitrite dynamics in the GOA. We expect similar processes to be operating in oligotrophic open ocean settings. We demonstrate here that the temporal variations in the depth profiles of nutrients enabled quantification of the dynamics in nutrient cycling processes. The close proximity of the GOA deep-water column to the shore, the calm waters, and limited external nutrient inputs (due to the hyper-arid continental area surrounding the Red Sea) facilitated high-resolution sampling in time and space. The water column of the GOA fluctuates seasonally between mixing and stratification that is reflected by a well-defined seasonal cycle of temperature, macronutrients (Lazar et al. 2008) and phytoplankton. During the winter (December to February), exceptionally deep convective mixing, reaching occasionally down to $800 \mathrm{~m}$ (Wolfvecht et al. 1992, Lazar et al. 2008) supplies surface waters with nutrients, elevating the primary productivity to values ranging between 0.03 and $0.05 \mathrm{~mol} \mathrm{C} \mathrm{m}^{-2} \mathrm{~d}^{-1}$ (Iluz 1998). In the spring (March to April) when surface water warms and stratification starts, a shallow-water phytoplankton bloom rapidly exhausts the nutrients within the photic zone (Mackey et al. 2007, Lazar et al. 2008). Following the short intensive bloom, a well-defined summer ther- 
mocline develops (May to October). During the summer, the thermocline extends down to 250-300 m, the photic zone varies between 80 and $115 \mathrm{~m}$ (Stambler 2006) and primary production is low, $\sim 0.02 \mathrm{~mol} \mathrm{C}$ $\mathrm{m}^{-2} \mathrm{~d}^{-1}$ (Iluz 1998). Several studies describe nutrient distributions in the GOA (e.g. Genin et al. 1995, Post et al. 2002, Mackey et al. 2007); only a few deal specifically with nitrogen dynamics (Al-Qutob et al. 2002, Badran et al. 2005, Lazar et al. 2008). To date, however, no study has evaluated the role of ammonium in controlling the water column nitrite distribution and the nitrogen cycle in the GOA.

This study was an attempt to quantify and understand the water column dynamics of nitrite from the variations in the depth profiles induced by the annual mixing and stratification cycle. We measured vertical profiles of all dissolved inorganic nitrogen (DIN) species and chlorophyll at high resolution on annual and diel time scales. The collective data suggested that nitrification is the dominant mechanism forming the PNM during most of the year except for the mixing period. We suggest that the PNM is maintained by a series of decomposition/oxidation processes. Our results were also consistent with the suggestion that during convective mixing, nitrite accumulates mainly by phytoplankton excretion (Al-Qutob et al. 2002). A simple mass-balance model based on summer vertical profiles was used to estimate the ratios between the rate constants of the processes controlling DINspecies distribution in the GOA.

\section{MATERIALS AND METHODS}

\section{Field sampling}

Water samples were collected at Stn A, GOA, $\left(29^{\circ} 28^{\prime} \mathrm{N}, 34^{\circ} 55^{\prime} \mathrm{E}\right)$ in 2 sampling campaigns: (1) Once a month from March 2000 to December 2001 (Red Sea Peace Park Program) aboard the RV 'Sea Surveyor' and (2) 10 cruises during the spring and summer of 2008 aboard the RV 'Queen of Sheba' (projects: NATO 'Science for Peace', the National Monitoring Program and Group for Aquatic Productivity). Two additional sampling campaigns were conducted for studying the diurnal fluctuations in the vertical distribution of nutrients during the summer stratified period: (1) 7 depth profiles per $24 \mathrm{~h}$ between 12 and 13 September 2000, and (2) 6 depth profiles per $24 \mathrm{~h}$ between 22 and 23 July 2001.

A CTD-Rosette (SeaBird) equipped with 11 Tefloncoated Niskin bottles (12 1 each), a CTD (SBE 19-02, SeaBird), Photometer, LICOR (LI-190SA) and a Fluo- rometer (Sea-Point Sensors) were used for continuous profiling and water sampling. Two CTD-Rosette casts were conducted at each station: a deep cast from the thermocline down to $700 \mathrm{~m}$ and a shallow cast from the surface down to the thermocline. Each cast included continuous profiles of temperature, salinity, light and chlorophyll fluorescence, and discrete water sampling for oxygen, nutrients, chlorophyll a (chl a) and cell counts.

On-board water sampling for nutrients, ammonium and chl a was conducted as follows. Duplicate water samples for nitrite and nitrate analyses were collected into $14 \mathrm{ml}$ polyethylene vials from the Niskin bottle, using a clean silicon tube. The tube was thoroughly flushed with the sample water and the vials were rinsed 3 times before filling. Samples were stored onboard at $4^{\circ} \mathrm{C}$ immediately after sampling and analyzed for nitrate and nitrite within a maximum of $4 \mathrm{~d}$ (see 'Analytical procedures' below). Water for ammonium analysis was sampled using a $5 \mathrm{ml}$ syringe connected by tygon tubing directly to the Niskin spigot in order to avoid any ship engine exhaust contamination. Samples $(4 \mathrm{ml})$ were taken in triplicates or quadruplicates and dispensed into $14 \mathrm{ml}$ polyethylene vials. Both syringe and vials were rinsed 3 times with sample water before filling. All ammonium analyses were conducted on-board during the cruise.

Samples for the chl a measurements were collected from the Niskin bottle in $500 \mathrm{ml}$ plastic bottles prerinsed with sample water. Samples were kept in dark containers and processed within $8 \mathrm{~h}$ of sampling.

\section{Analytical procedures}

Chl a. Samples $(250 \mathrm{ml})$ were concentrated on $25 \mathrm{~mm}$ Whatman GF/F filters, extracted overnight in $90 \%$ acetone and measured using the fluorometric method described by Parsons et al. (1984). Extracted $\mathrm{chl}$ a measurements were used to calibrate the in situ fluorescence profiles measured during the same hydrocast. The CTD fluorescence profiles for hydrocasts with no extracted chl a were calibrated using extracted chl a data from the closest sampling dates.

Nitrite and nitrate. Colorimetric analyses (Grasshoff et al. 1999) were conducted using a Flow Injection Autoanalyzer (FIA, Lachat Instruments Model QuikChem 8000). The analyses were fully automated and peak areas were calibrated using standards prepared in nutrient-deplete filtered seawater (surface seawater sampled during the most oligotrophic season in the GOA). Standards concentrations ranged 
from 0 to $5 \mu \mathrm{mol} \mathrm{l}^{-1}$. The limit of detection was $0.02 \mu \mathrm{mol} \mathrm{l}^{-1}$ and the precision was \pm 0.02 and $\pm 0.05 \mu \mathrm{mol} \mathrm{l}^{-1}$ for nitrite and nitrate, respectively. The same precisions were found between duplicate analyses of sample splits measured immediately after sampling and after the maximum refrigeration period.

Ammonium. Ammonium concentration was determined using a modified fluorometric method (Protocol A of Holmes et al. 1999; details of the modified protocol are given in Supplement 1 at www.int-res. com/articles/suppl/m453p011_supp.pdf). Samples were spiked with a stable working reagent, orthophthaldialdehyde (OPA), which forms a fluorescent complex with ammonium. The samples were incubated for $3 \mathrm{~h}$ and measured onboard with a Hoefer (DyNA QuantTM 200) fluorometer. The standard deviation was determined to be $\pm 0.009 \mu \mathrm{mol} \mathrm{l}^{-1}$ and the detection limit of this modified ammonium analysis was $\sim 0.0035 \mu \mathrm{mol} \mathrm{l^{-1 }}$.

\section{Calculations and uncertainties}

Water column inventories of measured concentrations of nitrate, nitrite and chl a were calculated by integrating them over a standard water column of $700 \mathrm{~m}$ depth. Nitrite and nitrate integrals were determined using the average of the duplicate samples and reported here in either $\mathrm{mol} \mathrm{m} \mathrm{m}^{-2}$ or $\mathrm{mmol} \mathrm{m} \mathrm{m}^{-2}$. $\mathrm{Chl}$ a inventories were calculated using the calibrated fluorescence profiles of 2 downcasts per station and reported here in $\mathrm{mg} \mathrm{m}^{-2}$. Before calculation the profiles were smoothed using a spline function. Inventory estimate error was $\sim 2 \%$ as determined by the difference between the integrals of each duplicate profile.

The depth of the mixed layer was taken as the vertical location of the maximum in the temperaturedepth derivative. The locations of the PNM, AM and DCM were the depths of the maximum concentrations of nitrite, ammonium and chl $a$, respectively. The uncertainty in the locations is estimated to be $\pm 5 \mathrm{~m}$ because the sampling intervals at this depth range were $10 \mathrm{~m}$.

In order to obtain only the biogeochemical signals, the vertical profiles from the diurnal cycles campaigns were processed to filter out vertical fluctuations stemming from the semi-diurnal (tidal) internal waves. The effect of internal waves was filtered out by arbitrarily adjusting the depths for all profiles from one sampling campaign to match the vertical density distribution of one of the middle profiles. The measured variables are reported versus their adjusted depth.

\section{RESULTS}

The nutrient regime in the GOA is controlled by the annual mixing-stratification cycle. There are 3 distinct periods: (1) winter mixing, (2) spring transition and (3) summer stratification. Water column profiles of temperature, chl $a$ and DIN species in representative periods of water column stability episodes, are presented in Figs. 1 \& 2. For the sake of clarity, all variables, except temperature, are shown as fractions of the maximum value. The actual concentrations are provided in Figs. S1 to S5 in Supplement 3 at www.int-res.com/articles/suppl/m453p011_supp.pdf.

\section{Winter mixing period (September to March)}

During the winter mixing period (as seen in the temperature profile, e.g. Figs. 1a \& 2a), the nitrite mixed layer inventory and concentrations were higher than those during the summer stratification period (Figs. S1a-g \& S2a-h in Supplement 3), reaching values comparable to those of nitrate. Ammonium concentrations were sometimes high at the beginning of the mixing period but generally low with values of $\sim 0.02 \mu \mathrm{mol} \mathrm{l}^{-1}$ for the the mixing season (Figs. S1a,g \& S2a,h in Supplement 3). Nitrate concentrations in the mixed layer increased gradually while the mixed layer deepened and extended below the summer nitracline (Fig. 1a,e,f, Figs. S1a,g \& S2a,h in Supplement 3). Chl a concentrations were uniform $\left(\sim 0.2 \mu \mathrm{g} \mathrm{l}^{-1}\right)$ throughout the mixed layer (Fig. 1e,f, Figs. S3a,g \& S4a,h in Supplement 3), and the inventory increased with the deepening of the mixed layer. When short periods of warm weather stopped the active mixing temporarily, the chl a profile showed a distinct near-surface maximum (Figs. 1a \& 2a).

\section{Spring transition period (March to May)}

Each spring, at the onset of stratification, surface $(\leq 50 \mathrm{~m}$ ) bloom conditions developed (Figs. 1b,c,g,h \& $2 \mathrm{~b}-\mathrm{d}$ ) as indicated by maximum $\mathrm{chl}$ a concentrations reaching 0.5 to $1.5 \mu \mathrm{g} \mathrm{l}^{-1}$ (Figs. S3b,c, S4b-d \& S5b-e in Supplement 3). In the same period, the chl a concentrations below the photic zone followed an exponential decay curve (Figs. 1c \& 2b,c) and decreased throughout the spring due to the mortality of phytoplankton trapped at depth. The water column during this transition period was characterized by short alternations between mixing and stratification condi- 

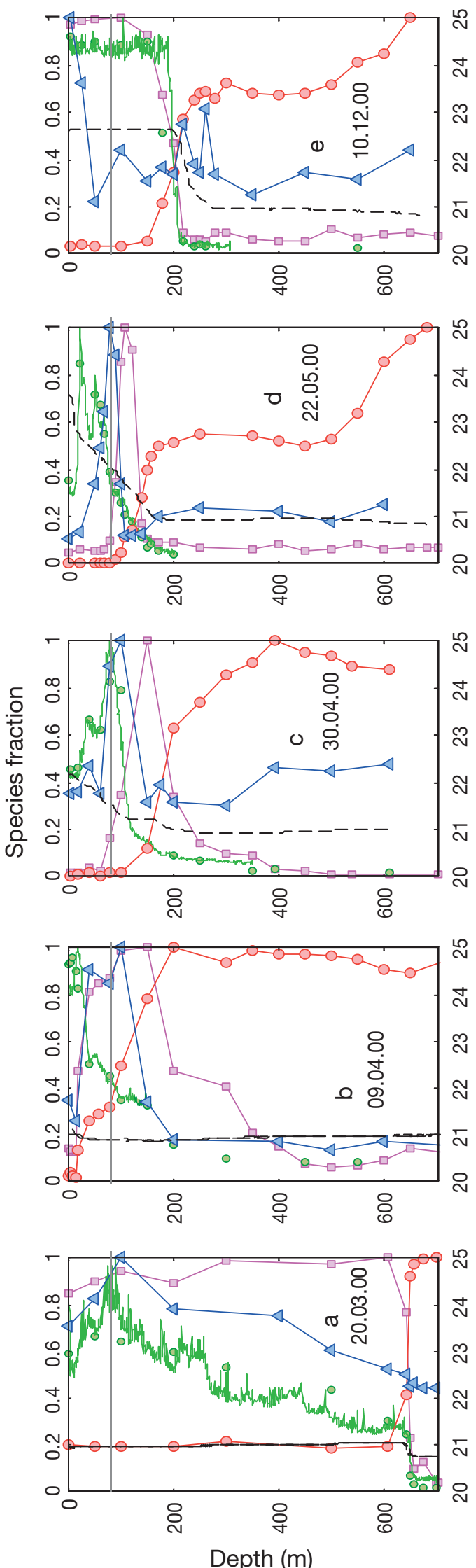

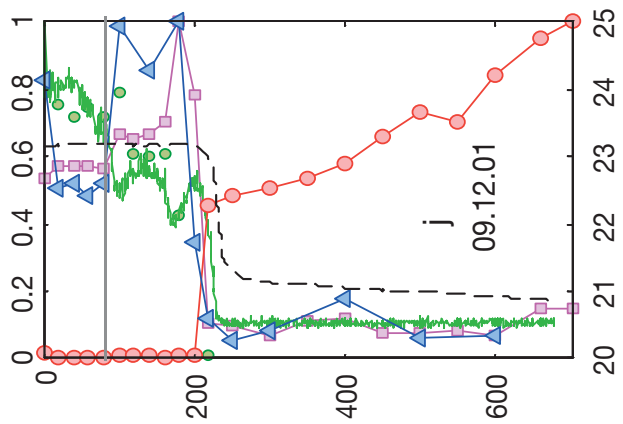

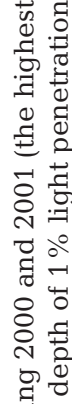

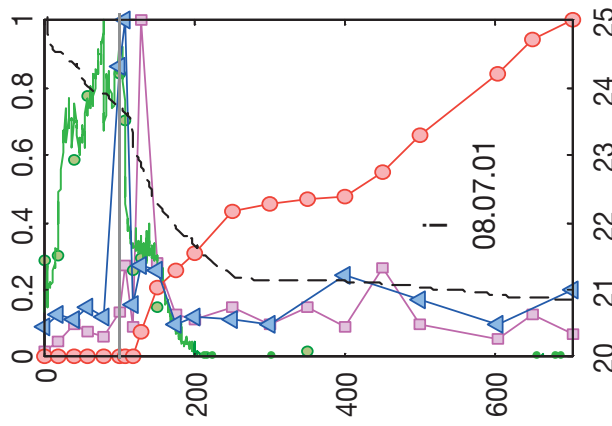

寻

বㅇํㅇ

氮

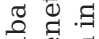

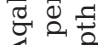

药

녁 융

$<-\frac{1}{0}$

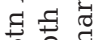

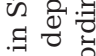

됴월

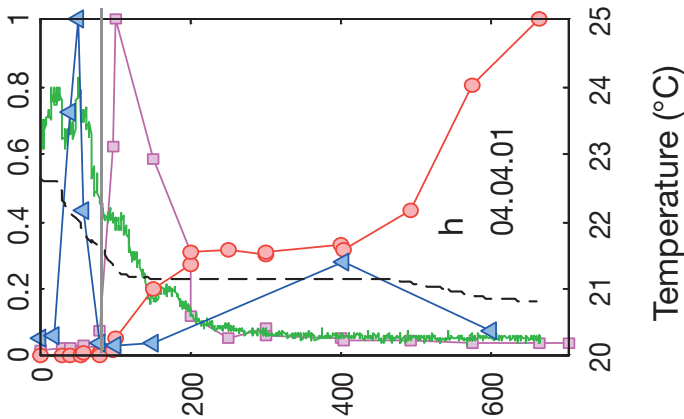

茫

品零

$\stackrel{0}{0}$

ष

읭

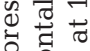

究

웡

궁

윻ํㅇ

ช 듬

वि $\dot{\vec{\lambda}}$

욜

छี 웡 छ

:

명

政

E

ब苟

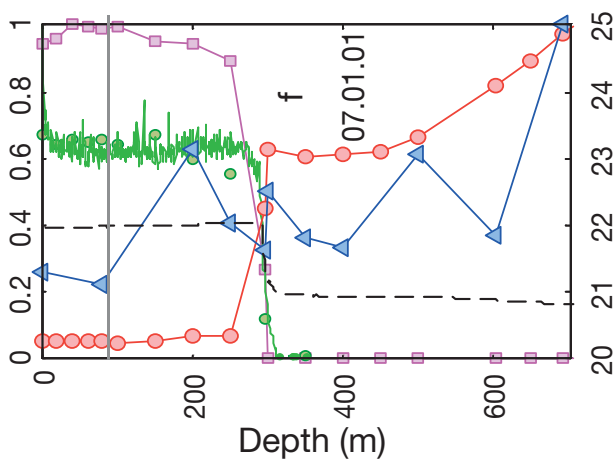



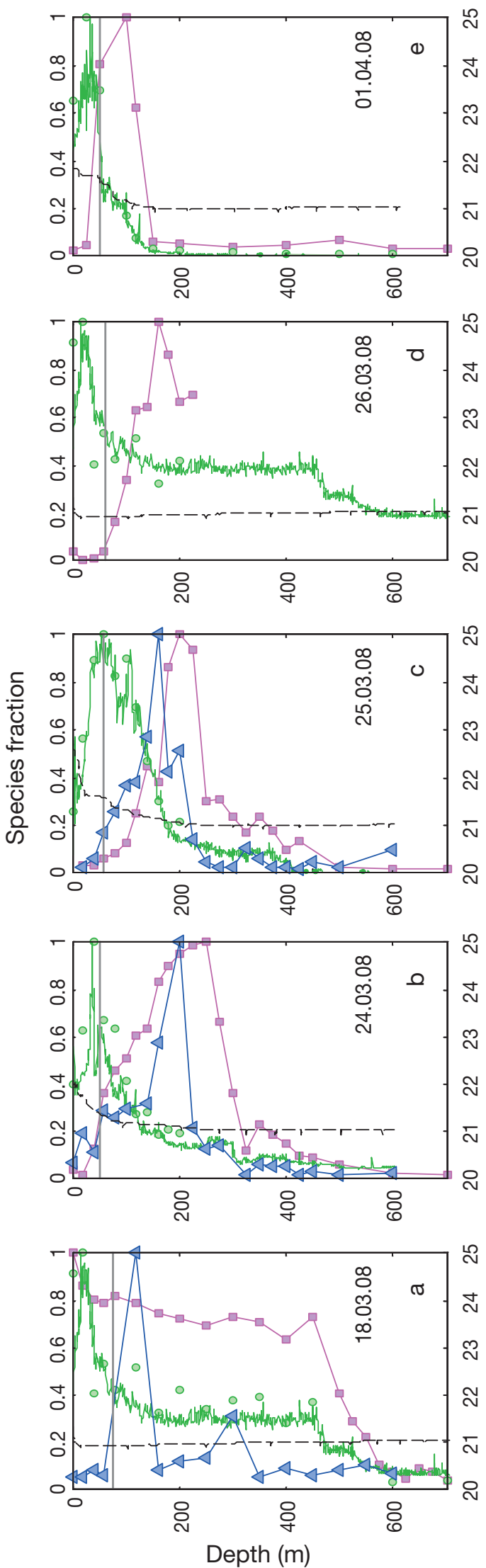
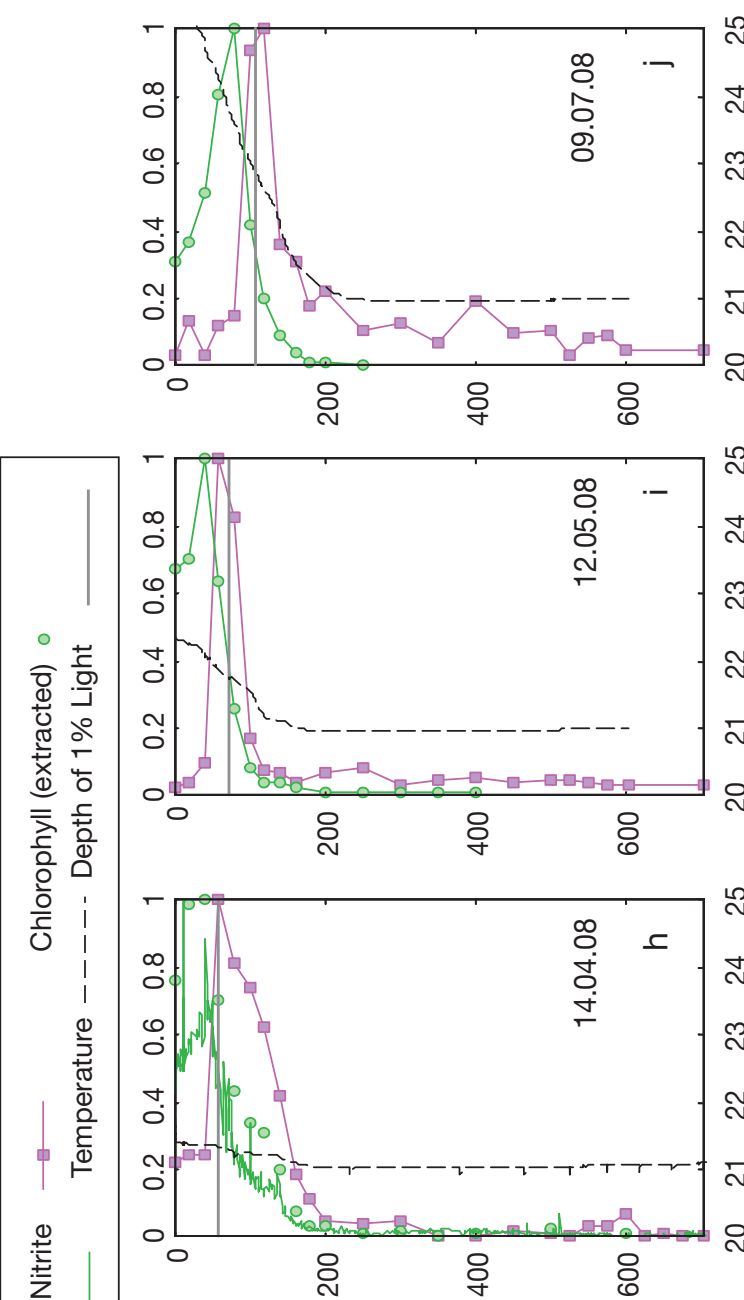

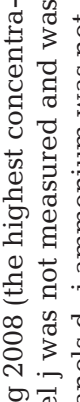

एँ

궁. 쿄

过

용

तै

近要

항혀

ช ㅇํํำ

$\varangle=$

兒考导

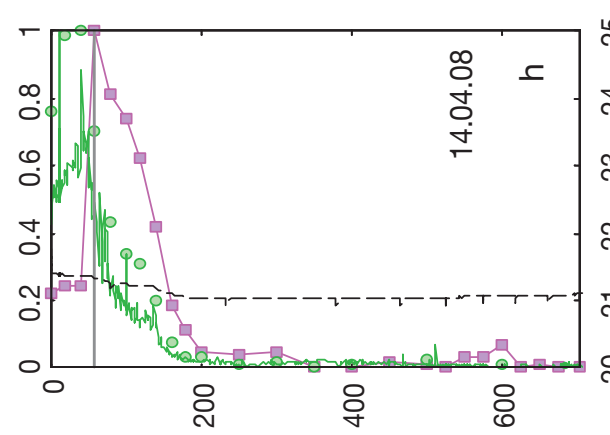

ฐ 웡

O 兘焉

의 의 है

尊 要

o 0

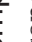

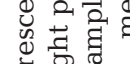

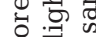

矛 。ํㅇㅇ

0

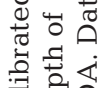
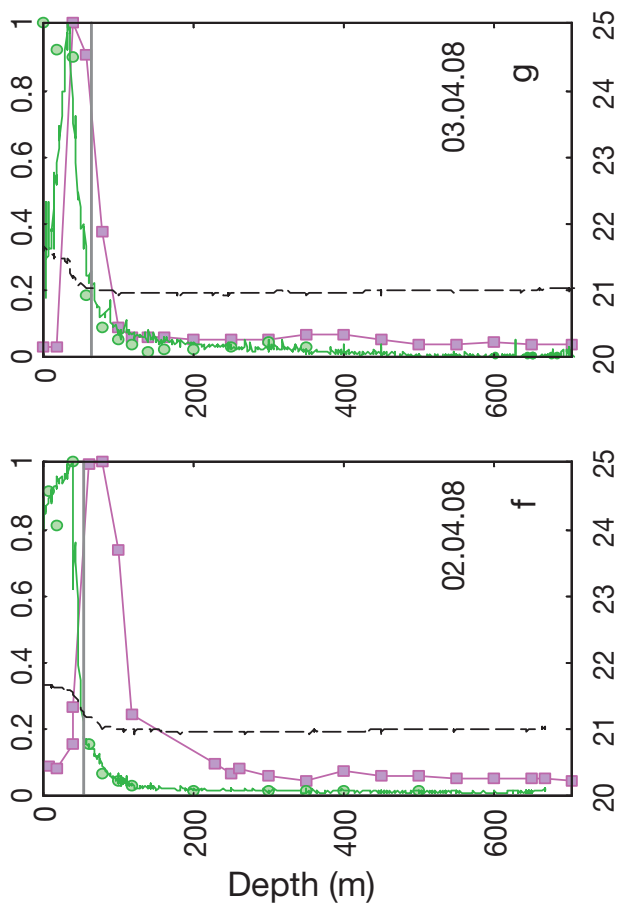

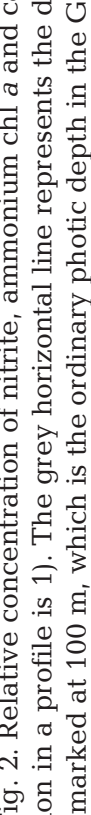


tions as seen in the temperature profiles measured at high temporal resolution (Fig. 2a-d). Chl a concentrations responded sharply to these short alternations until a stable stratification was achieved (Figs. 1b,g $\& 2 \mathrm{a}-\mathrm{d})$.

Nitrate concentrations in surface water decreased rapidly due to consumption by phytoplankton (Fig. 1b,c,g,h, Figs. S1b,c \& S2b-d in Supplement 3) and a transitional nitracline developed within the photic zone. Later, with the development of summer stratification, the nitracline descended to the base of the photic zone. Ammonium and nitrite accumulated primarily below the photic zone (Figs. 1b,c,g,h \& 2b,c, Figs. S1b,c \& S2b-d in Supplement 3) which was relatively shallow (ca. $60 \mathrm{~m}$ ) due to the spring bloom. This phenomenon was very pronounced during a time series sampling conducted in spring 2008 (Fig. 2, Fig. S5b,c and Fig. S5d only for nitrite in Supplement 3). This accumulation was most likely due to decomposition of phytoplankton 'trapped' at depth at the onset of stratification.

A careful inspection of the nitrite and ammonium dynamics during transition period, especially of the detailed sampling during 2008, revealed 3 consecutive stages in the development of the PNM: (1) a wide, large and deep nitrite peak, (2) a sharp, large and shallow nitrite peak and (3) the beginning of a typical PNM structure.

(1) A wide, large and deep nitrite peak (Figs. 1b,g \& 2b-d, Figs. S1b,c, S2b,c, S3b,c, S4b,c \& S5 b-d in Supplement 3). At the onset of stratification, when chl a was still present in deep water, a wide nitrite peak formed extending from near the surface layer $(20 \mathrm{~m})$ down to $300 \mathrm{~m}$. In spring 2008, the nitrite inventory increased by a factor of 1.3 over $1 \mathrm{wk}$ at the transition between mixing and beginning of stratification (from $90 \mathrm{mmol} \mathrm{m}^{-2}$ on March 18 to $120 \mathrm{mmol}$ $\mathrm{m}^{-2}$ on March 24, calculated from the area under the curve of the nitrite profiles in Fig. S5a,b in Supplement 3). A maximum nitrite concentration of $0.54 \mu \mathrm{mol}$ $\mathrm{l}^{-1}$ was measured in the new peak. The peak was located at a depth of $\sim 250 \mathrm{~m}$, well below the photic zone (even for the clearest water column conditions in the GOA). Specifically at this time the photic zone was relatively shallow due to the surface phytoplankton bloom (Fig. 2b). The response of the $\mathrm{N}$ system was very fast as demonstrated by the narrowing and sharpening of the nitrite peak over the following $2 \mathrm{~d}$, March 25 and 26 (Fig. 2c,d, Fig. S5c,d in Supplement 3). Nitrite peak concentration increased to $0.61 \mu \mathrm{mol}$ $\mathrm{l}^{-1}$, and the peak position rose up to a depth of $\sim 160 \mathrm{~m}$, still below the photic zone, while its inventory decreased (e.g. the peak narrowed). The ammonium peak appeared together with the nitrite peak, slightly above it, and roughly followed the trend in nitrite.

(2) A sharp, large and shallow nitrite peak (Figs. 1c,h \& 2e-g, Figs. S1c, S2c,d, S3c, S4c,d \& S5e-g in Supplement 3). The nitrite peak narrowed considerably while ascending towards the chl a peak, crossing the depth of $1 \%$ light. The nitrite peak reached the shallow depth of $40 \mathrm{~m}$, its maximum value increased to $0.83 \mu \mathrm{mol} \mathrm{l^{-1 }}$, and its inventory decreased from 94 to $67 \mathrm{mmol} \mathrm{m}^{-2}$ as shown on $3 \mathrm{con}$ secutive profiles during a week with spring bloom conditions (Fig. 2e-g, inventories are calculated from the area under the curve of the nitrite profiles in Fig. S5e-g in Supplement 3). By that time, deepwater chl a levels had decreased to zero while chl a concentrations in the surface increased substantially due to the development of a phytoplankton bloom.

(3) Beginning of a typical PNM structure (Fig. 1d \& $2 i$, Figs. S1d \& S5i,j in Supplement 3). The nitrite concentration in the broad nitrite peak decreased considerably to concentrations more similar to the typical PNM of the stratified period (0.2 to $0.5 \mu \mathrm{mol} \mathrm{l}^{-1}$, Figs. S1d \& S5i in Supplement 3). The PNM position stabilized at $\sim 20 \mathrm{~m}$ below the DCM. Its peak value and inventory decreased to the lowest values in the sequence described above (i.e. the whole transition period), $0.28 \mu \mathrm{mol} \mathrm{l}^{-1}$ and $28 \mathrm{mmol} \mathrm{m}^{-2}$, respectively. Over the following months the nitrite inventory and its peak concentration further decreased by $\sim 30 \%$, assuming its summer position relative to the DCM and its typical PNM shape (Fig. 5i,j).

\section{Summer stratification period (June to September)}

During summer, nitrate concentrations from the surface down to $\sim 100 \mathrm{~m}$ were below the level of detection $\left(<0.05 \mu \mathrm{mol} \mathrm{l}^{-1}\right.$, Figs. 1d,i, Figs. S1e,f \& S2e-g in Supplement 3). A sharp nitrate gradient (nitracline) had established near the base of the photic zone $(\sim 100 \mathrm{~m})$ extending down to $\sim 200 \mathrm{~m}$. Below $200 \mathrm{~m}$, nitrate increased gradually, reaching a maximum value of $\sim 6.5 \mu \mathrm{mol} \mathrm{l}^{-1}$ at the end of the period (Fig. S2g in Supplement 3). Chl a profiles showed the typical DCM shape with concentrations reaching $0.4 \mathrm{\mu g} \mathrm{l}^{-1}$ (Fig. 1d,i, Figs. S3d-f \& S4e-g in Supplement 3). The DCM location descended throughout the summer to a maximum depth of $\sim 100 \mathrm{~m}$. Below the DCM chl a values decreased exponentially.

Concentrations of nitrite and ammonium between the surface and the DCM were very low; nitrite was 
usually below the detection limit $\left(<0.02 \mu \mathrm{mol} \mathrm{l}^{-1}\right)$ and ammonium ranged between 0.008 and $0.01 \mu \mathrm{mol} \mathrm{l^{-1 }}$. Nitrite and ammonium concentrations formed 2 distinct and narrow ( $20 \mathrm{~m}$ wide) peaks below the DCM (Fig. 1d,i, Figs. S1d,f \& S2f in Supplement 3), which were at the AM and 10 to $15 \mathrm{~m}$ deeper than the PNM. The PNM was symmetric; its location fluctuated below and above the base of the photic zone just at the top of the nitracline. The maximum values of the PNM were between 0.065 and $0.35 \mu \mathrm{mol} \mathrm{l}^{-1}$ and the maximum values of the AM reached 0.05 to $0.1 \mu \mathrm{mol}$ $1^{-1}$ (Figs. S1d,f \& S2f in Supplement 3).

The DCM and PNM were constant features of the water column during stratification. The AM on the other hand was an irregular feature, occasionally disappearing (Figs. S1e \& S2e in Supplement 3). When present, the AM position was 10 to $15 \mathrm{~m}$ above the PNM, and the 2 peaks were slightly overlapping. When the AM was absent, the PNM invariably took its place right below the DCM. The depth fluctuations of the 2 peaks during summer occurred in concert with the variation in the depth of the nitracline as well as with that of the DCM.

\section{Chl $a$ and $\mathrm{N}$-species during a diurnal cycle}

Depth profiles of chl a showed a clear diurnal pattern above the DCM in 2 consecutive summers. Chl a concentrations fluctuated diurnally, being high during daytime and low during the night (Fig. 3a,e). Below the DCM, the chl a depth profile showed a clear monotonic decay with depth with no diurnal fluctuations. The vertical location of the PNM (Fig. $3 \mathrm{~b}, \mathrm{f}$ ) and the nitrate profiles (Fig. 3d,h) did not fluctuate significantly during the diurnal cycle. Ammonium showed a peak between the DCM and the PNM during July 2001, but AM was hard to detect in September 2000 (Fig. 3c,g). When the AM was absent, the PNM rose to a position closer to the DCM, as described for the summer stratification above.

\section{DISCUSSION}

Nitrite inventory in the water column of the GOA fluctuated considerably by about an order of magnitude between seasons (Fig. 4). Nitrite inventory was

12-13 September 2000
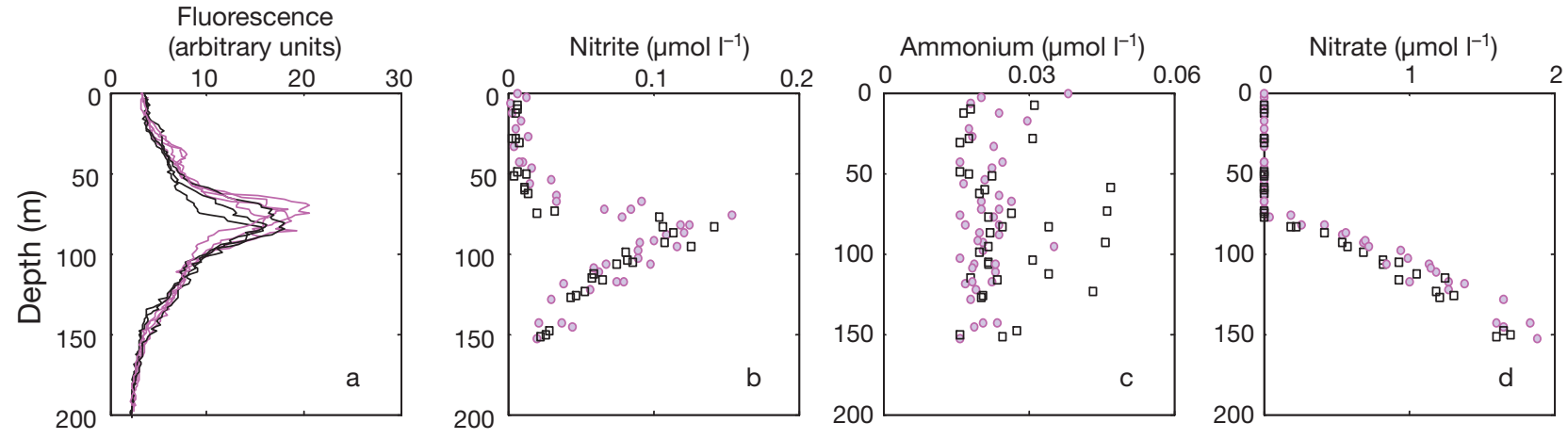

22-23 July 2001
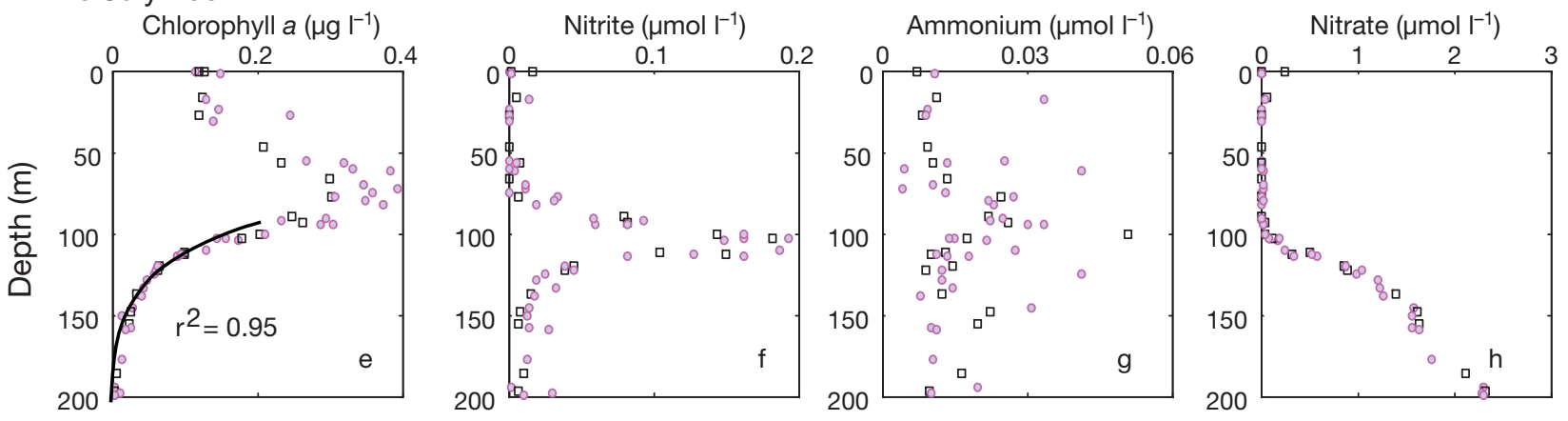

Fig. 3. Chl a, nitrite, nitrate and ammonium levels during 2 diurnal cycles: (a-d) 7 depth profiles in September 2000 and (e-h) 6 depth profiles in July 2001. In all panels, pink represent daylight samples and black night samples. In panel a, the chl $a$ is reported as CTD fluorescence arbitrary units. The smooth line in panel e is the best exponential fit of all the samples deeper than $95 \mathrm{~m}\left(\mathrm{r}^{2}=0.95\right)$ 


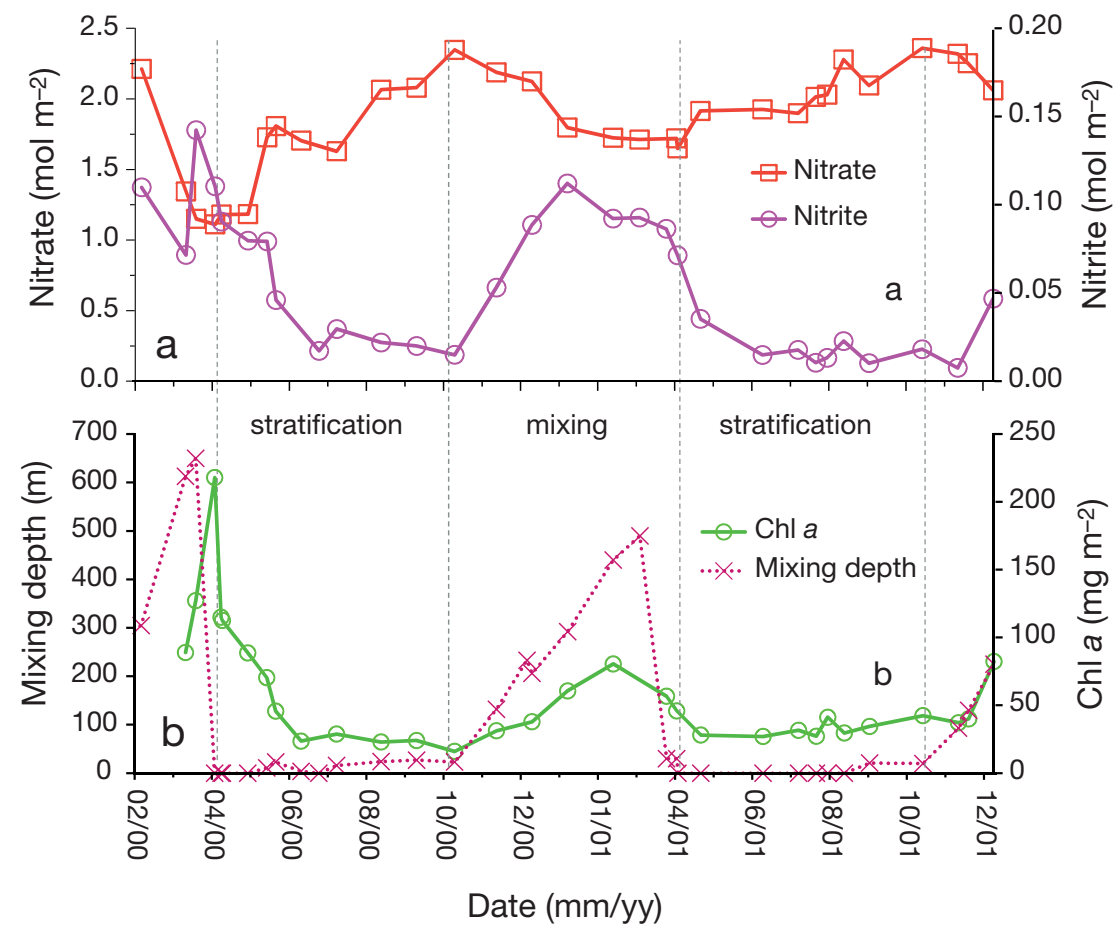

Fig. 4. Time series data from Stn A during 2000 and 2001 of water column $(0-700 \mathrm{~m})$ inventories (a) of nitrate and nitrite and (b) chl $a$ and mixing depth. The estimated error is smaller than the marker size and therefore not presented.

Mixing and stratification periods are separated by the dashed vertical lines

\section{Nitrite dynamics at the onset of stratification}

The onset of stratification provided an opportunity to study the development of the PNM (Figs. 1b,g \& 2b, Figs. S1b,c, S2b,c, \& S5b-d in Supplement 3). It was characterized by major changes in water column $\mathrm{DIN}_{i}$ the nitrate in the photic zone was consumed, the nitracline formed and the nitrite and ammonium content in the upper $300 \mathrm{~m}$ increased markedly. The ammonium increase was most probably a result of ammonification during the decomposition of the abundant eukaryotic phytoplankton population (mainly diatoms; Lindell \& Post 1995) 'trapped' at depth at the end of the mixing period, by stratification. A similar link between ammonium accumulation and the crash of a diatom bloom was described in the Atlantic Ocean (Johnson et al. 2007). Microbial oxidation of this ammonium results in nitrite accu-

highest during the mixing period and its concentrations reached a maximum at the onset of the stratification period when nitrite accumulated between the surface and $300 \mathrm{~m}$ (Figs. 1b,c,g,h \& 2b-d, Figs. S1b,c, S2b,c \& S5b-d in Supplement 3). Minimum nitrite inventories and concentrations were observed during the summer stratification (Figs. 1d,i \& 2i,j, Figs. S1e,f, S2d-g \& S5i,j in Supplement 3). These variations and their relations with $\operatorname{chl} a_{\text {, }}$ nitrate and ammonium on annual and daily cycles are used here to identify the main processes controlling nitrite water column dynamics. We examine the role of phytoplankton excretion and differential photoinhibition (Olson 1981, Lomas \& Lipschultz 2006) in producing the water column PNM. An additional suggested mechanism, differential photorecovery (Guerrero \& Jones 1996b), is not considered here because it cannot operate under the hydrographic conditions in the GOA (see Supplement 2 at www.int-res.com/articles/suppl/m453 p011_supp.pdf for explanation). In addition, we explain below the vertical order and separation of $\mathrm{N}$-species in the summer water column as a combined process of transport and reaction and estimate the ratios between the rate constants of the main $\mathrm{N}$-transformation processes. mulation, thus the nitrite-ammonium correlation implies that nitrite was produced from ammonium oxidation, a process mediated by microbes.

A deep and wide nitrite peak was formed below the ammonium maximum during a period of several weeks following the onset of stratification (Figs. 1b,c,g,h $\& 2 b-f)$. The maximum concentrations of ammonium and nitrite (and hence their maximum accumulation rates) occurred well below the photic zone, in the depth range of decreasing chl $a$. The further decrease in ammonium and nitrite concentrations later on suggests that the high ammonium and nitrite at the onset of stratification were associated with mortality of 'trapped' phytoplankton. We therefore conclude that microbial oxidation of ammonium released by the decomposing phytoplankton community (ammonification) was the prime contributor to nitrite accumulation during the onset of stratification.

In conjunction with the accumulation of ammonium and nitrite below the photic layer, an inverse relation between chl $a$ and nitrite inventories was observed in surface waters. Clearly seen during 24 to 26 March 2008, the photic layer was characterized by an increase in chl a inventory (phytoplankton bloom) that was mirrored by a decrease in the upper $100 \mathrm{~m}$ nitrite and nitrate inventories (Fig. 5). This is in con- 


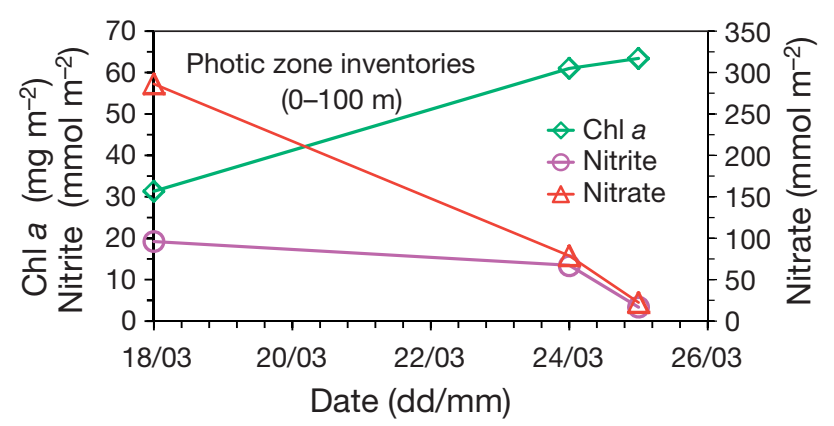

Fig. 5. Time variability of nitrite and nitrate inventories and chl $a$ in the photic zone (upper $100 \mathrm{~m}$ ) at Stn A during the onset of stratification (March 2008). The estimated error is smaller than the marker size and therefore not presented

trast to the trends found at the same time below the photic layer where nitrite inventory increased and chl a content decreased. In the photic zone the decrease in nitrate and nitrite appears to have stemmed from phytoplankton consumption during the bloom (as reflected by the chl a increase; Lindell \& Post 1995). These results suggest that during the vernal bloom active phytoplankton consume nitrite within the photic zone rather than excreting it.

\section{Diel magnitude, vertical position and shape of the summer PNM and DCM}

The PNM did not fluctuate over a diurnal cycle. Its vertical position, magnitude, shape and distance from the bottom of the mixed layer were all constant (Fig. 3b,f). The diel constancy of the PNM characteristics could suggest that light dependent mechanisms proposed for producing the PNM-like phytoplankton excretion and differential photoinhibition (Olson 1981, Collos 1998) did not play a significant role during summer stratification, otherwise they would be expected to yield either a diel vertically migrating PNM or increase in nitrite concentration at night within the photic zone. Here we evaluate the role of each of the 2 mechanisms in the formation of the summer PNM in view of the nitrite and chl a diurnal profiles.

Differential photoinhibition. The constant position of the PNM at the base of the photic zone indicates that at this depth range nitrifying bacteria populations are not affected by the diurnal fluctuations of the light regime. It is possible, however, that the reason for the abundance and activity of nitrifying bacteria at this depth is to avoid the negative impacts of light. Regardless of the specific controls on the nitrifying bacteria populations, this distribution suggests that once the PNM is established, differential photoinhibition is not a key process controlling the PNM because the PNM is positioned at a depth where the maximum diurnal light intensity is lower than the minimum required for inhibiting the activity of nitrifier populations.

Phytoplankton excretion. Phytoplankton populations become stressed and start to decline when transported within the thermocline (by sinking and turbulence) to depths at which daytime light intensity is lower than the minimum required for net population growth. The stressed phytoplankton population may excrete nitrite and produce a PNM (Wada \& Hattori 1971, Kiefer et al. 1976, Collos 1998). If this is a major mechanism for forming the PNM, we would expect the PNM to oscillate vertically, forced by the exposure to the diurnally oscillating light regime.

The phytoplankton population transported to the base of the photic zone could be constantly stressed (even in the maximum diurnal light intensity), hence they are responsible for forming a vertically stationary PNM. However, in this case we think that the nitrite peak would be much broader (at least during night) and would not possess the sharp and thin maximum characteristics of the observed nitrite peak (Figs. 1i, 2j \& 3b,f). This is because the upper part of the PNM is within the depth range in which the chl a concentration fluctuates diurnally (e.g. it is within the photic zone; Figs. 3a,e \& 6). If the observed chl a fluctuations stem from diurnal fluctuations in phytoplankton population, then the depth zone of nitrite excretion by stressed phytoplankton should oscillate diurnally, leading to broadening of the nitrite peak.

The observed chl a oscillations in the GOA likely result from the daytime increase and nighttime decrease in the phytoplankton population (e.g. cell growth and grazing) rather than variations in the chl a content of each cell (Le Bouteiller \& Herbland 1982, Blanchot et al. 1997, Vaulot \& Marie 1999). This is because chl a content in each cell would show an increase in the evening (Vaulot \& Marie 1999), the opposite of the observed diel behavior of chl a concentrations in this study (Figs. 3a,e \& 6). Thus, the coexistence of an invariant nitrite profile with a diurnally oscillating phytoplankton population above the DCM suggests that phytoplankton excretion of nitrite was not the main process forming the summer PNM.

Without correcting the profiles for vertical fluctuation caused by internal waves and sampling at high vertical resolution, the patterns observed would not have been clear and may have led to inaccurate interpretation of the results (see 'Materials and methods'). The diel oscillations in the PNM profile found 


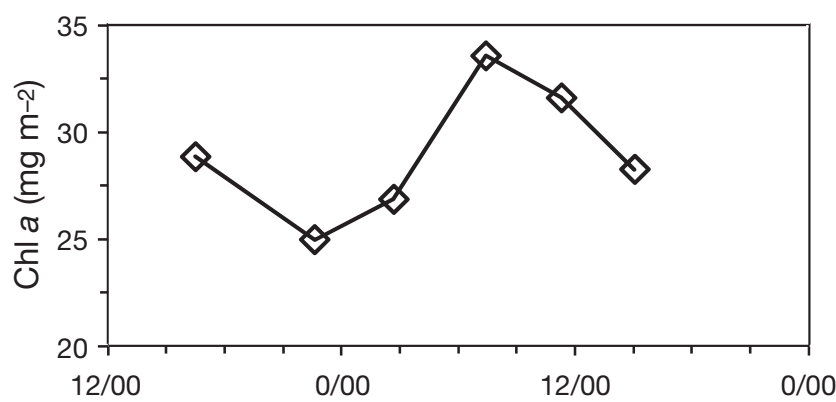

Fig. 6. Diurnal cycle of chl a inventory (0-200 m) on 22-23 July 2001 at Stn A. The estimated error is the size of the marker

in earlier studies (French et al. 1983, Al-Qutob et al. 2002; the second study was conducted in the GOA with common co-authors to the present study) may have been affected by the semi-diurnal (tidal) internal waves and the low vertical resolution sampling of the profiles. The PNM diurnal oscillations led these studies to the conclusion that excretion by phytoplankton was the prime mechanism for nitrite accumulation.

In summary, the PNM characteristics discussed above imply that the most likely mechanism forming the summer PNM is nitrification at a vertical position deeper than a certain threshold. The maximum light intensity at this threshold depth has been suggested to be lower than the light intensity required for triggering nitrification by photoinhibition, even during daylight. We propose (below) that light intensity is not the only factor determining the position of maximum nitrification rates and hence the vertical position of the PNM. Other key factors are the downward sinking and turbulent flux of the decaying phytoplankton population and the rate constants of the various $\mathrm{N}$ transformation processes. These factors together determine the vertical position of the summer PNM.

\section{A transport-reaction control on the vertical distribution and separation of the $\mathrm{N}$-species during summer stratification}

The monotonic decrease in chl a below the DCM at a depth range where no diurnal fluctuations were detected (Fig. 3a,e) shows highly significant exponential behavior $\left(\mathrm{r}^{2}=0.95\right.$, Fig. 3e), suggesting control by transport and uptake/release reactions. A chl a mass-balance equation describing its steady state distribution below the DCM as a function of vertical transport and phytoplankton decomposition has the form:

$$
D_{\mathrm{T}} \times \frac{\mathrm{d}^{2}[\mathrm{chl}]}{\mathrm{d} z^{2}}-\frac{\mathrm{d}(S \times[\mathrm{chl}])}{\mathrm{d} z}-\mathrm{K}_{\mathrm{phyt}-\mathrm{NH}_{4}^{+}} \times[\mathrm{chl}]=0
$$

where [chl] is the chl a concentration, $\mathrm{K}_{\text {phyt-NH}}{ }_{4}^{+}$is the phytoplankton decomposition rate constant, $S\left(\mathrm{~m} \mathrm{~d}^{-1}\right)$ is the sinking velocity of particles, $Z(\mathrm{~m})$ is depth and $D_{\mathrm{T}}\left(\mathrm{m}^{2} \mathrm{~d}^{-1}\right)$ is the vertical turbulence coefficient. The analytical solution for this equation contains exponentials similar in shape to the best fit of the observed chl a profile (Fig. 3e). The chl a versus depth function suggests that chl $a$ is transported by turbulence and sinking, and the controlling process is net phytoplankton decomposition (the third term in Eq. 1). The appearance of the AM and PNM below the DCM in the region of exponential chl a decrease is consistent with the hypothesis that below the DCM ammonium accumulates by ammonification during phytoplankton decomposition (reaching a maximum at the AM $\sim 10 \mathrm{~m}$ below the DCM) and nitrite accumulates by oxidation (nitrification) of the formed ammonium (reaching a maximum at the PNM $\sim 15 \mathrm{~m}$ below the AM).

The hierarchical staggering of the DCM, AM, PNM and nitracline during the summer stratification gives additional evidence supporting transport and nitrification as a mechanism for the formation of the PNM. During the summer stratification the profiles of chl $a$, ammonium, nitrite and nitrate were vertically ordered; DCM was at the top followed by AM, PNM and the nitracline at the bottom (Fig. 1c,d,i). This is also the order of the $\mathrm{N}$-species according to their oxidation state from reduced $\mathrm{N}$ in particles to the most oxidized dissolved $\mathrm{N}$-species. The depth order of the $\mathrm{N}$-species is very similar in appearance to the time succession in closed system experiments on the aerobic decomposition of detrital particulate organic nitrogen (PON; Libes 1992) and may be indicating that nitrification is the process in hand. We suggest that the time axis in the closed system experiments is equivalent to the depth axis in the water column. Accordingly, we explain the vertical separation of the $\mathrm{N}$-species throughout the water column as a result of the travel time needed for a POM (particulate organic matter) particle formed at the DCM to sink and decompose to ammonium, which is being transported by turbulent mixing while oxidizing to nitrite and nitrate.

The time, $t$, that an $\mathrm{N}$-species travels from the DCM downward to the nitracline (the maximum depth derivative of the nitrate profile) is:

$$
t=t_{\mathrm{p}}+t_{\mathrm{d}}
$$


where $t_{\mathrm{p}}$ is the time that phytoplankton particles travel the distance $\Delta z_{\mathrm{p}} \approx 10 \mathrm{~m}$ from the DCM to the AM by sinking, and $t_{\mathrm{d}}$ is the time that a dissolved $\mathrm{N}$-species travels the distance $\Delta z_{\mathrm{d}} \approx 20 \mathrm{~m}$ from the AM to the nitracline by vertical turbulence. Accordingly:

$$
t \approx \Delta z_{\mathrm{p}} \times S^{-1}+\left(\Delta z_{\mathrm{d}}\right)^{2} \times D_{\mathrm{T}}^{-1}
$$

The overall vertical distance between the DCM and the nitracline $\left(\Delta z_{p}+\Delta z_{d}\right)$ is controlled by the rate of ammonification/nitrification and the rate of vertical transport by sinking (particles) and turbulence (particles and dissolved $\mathrm{N}$-species). The AM and PNM are located within this distance, separated vertically by the transport-reaction mechanism.

Particles that sink from the DCM produce the ammonium peak as they decay. The peak of the ammonium, which is the most reduced $\mathrm{N}$ form, is located $\sim 10 \mathrm{~m}$ below the DCM in the GOA, a distance representing the maximum downward flux of chl $a$. The AM depth is dictated by the rate of ammonification and the rate of vertical transport (sinking). Clearly, the ammonium maximum lies in the position of ammonium maximum net production rate, most likely at the maximum supply rate of chlorophyll $(\mathrm{d}[\mathrm{chl}] / \mathrm{d} z=$ maximum $)$. However, the ammonium vertical flux at the maximum (exactly at the AM) is zero (because the first ammonium/depth derivative equals zero, $\mathrm{d}\left[\mathrm{NH}_{4}{ }^{+}\right]_{\mathrm{AM}} / \mathrm{d} z=0$, where $\left[\mathrm{NH}_{4}{ }^{+}\right]_{\mathrm{AM}}$ is the ammonium concentration at the AM). From the AM, the ammonium flux increases upward $\left(\mathrm{d}\left[\mathrm{NH}_{4}{ }^{+}\right] / \mathrm{d} z<0\right)$ and downward $\left(\mathrm{d}\left[\mathrm{NH}_{4}{ }^{+}\right] / \mathrm{d} z>0\right)$ while it is being carried away by turbulent transport. On the way up the ammonium is being utilized by phytoplankton and on the way down (in the dark) it is oxidized to nitrite. Similarly to ammonium, the maximum of the nitrite peak (PNM) represents the location of maximum nitrite production rate and zero vertical flux $\left(\mathrm{d}\left[\mathrm{NO}_{2}{ }^{-}\right]_{\mathrm{PNM}} / \mathrm{d} z=0\right.$, where $\left[\mathrm{NO}_{2}{ }^{-}\right]_{\mathrm{PNM}}$ is the nitrite concentration at the PNM). Like ammonium, nitrite is transported via turbulent mixing, upward and downward. It is utilized by phytoplankton on the way up in the lighted areas and oxidized to nitrate on the way down in the dark. The PNM forms at a vertical distance below the AM, probably at the location in which the ammonium downward flux is maximum $\left(\mathrm{d}\left[\mathrm{NH}_{4}{ }^{+}\right] / \mathrm{dz}=\right.$ maximum). The ammonium rate of supply (controlled by the rate of ammonium oxidation and the rate of its dispersion by turbulence) determines the vertical distance between the AM (the position of maximum chl a supply and maximum ammonium production) and the PNM (the position of maximum ammonium supply and maximum nitrite production). A similar rationale explains why (in the absence of consumption processes) the rate of nitrate accumulation by nitrite oxidation (maximum nitrate slope), which is the most oxidized $\mathrm{N}$-species, is at a certain distance below the PNM.

This sequence of processes can operate during the whole stratified season only if the $\mathrm{N}$-reservoir of the photic zone is either continuously decreasing or continuously supplied with 'new' N. In the GOA, the sharp depth gradient of nitrate profile (Fig. 1d,i) indicates that nitrate is transported upward by turbulence. Atmospheric deposition and $\mathrm{N}$ fixation were also suggested as a possible sources of 'new' $\mathrm{N}$ in the GOA (Chen et al. 2007, Foster et al. 2009, Paytan et al. 2009, Wankel et al. 2010).

The conserved distribution of the N-species' peaks in the water column is best demonstrated by the correlation between the vertical positions of the PNM, DCM and nitracline (Fig. 7). Similar relationships were reported earlier between nitrite and the nitracline (Dore \& Karl 1996b, Lomas \& Lipschultz 2006) and between the DCM and PNM (Kiefer et al. 1976, French et al. 1983, Collos 1998). However, the relative depth distribution of all dissolved inorganic nitrogen species and chl a simultaneously was rarely described. During the summers, the ammonium peak was occasionally absent from the GOA profiles. In these cases, the PNM 'migrated' upward and occupied the virtual vertical position of the AM (Figs. S1e \& S2e, in Supplement 3). Apparently, the AM disappeared as its position in the water column merged with that of the PNM. Similar behavior of the PNM

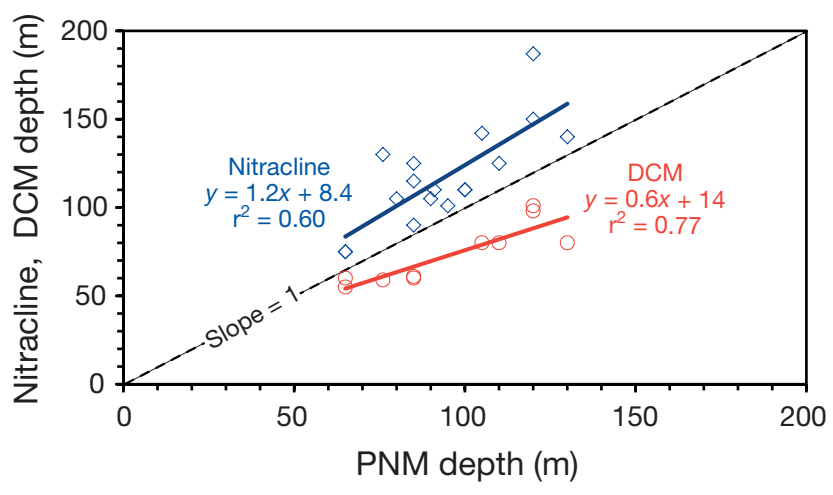

Fig. 7. Depths of the primary nitrite maximum (PNM) versus the depths of the deep chl a maximum (DCM) and the nitracline during 2000 and 2001 at Stn A. The depth of the nitracline is represented by the depth of maximum derivative of the nitrate profile. The dashed line represents the unity slope. The linear trendlines representing the depths of the DCM versus the PNM $\left(\mathrm{r}^{2}=0.6\right)$ and the depths of the nitracline versus the PNM $\left(r^{2}=0.8\right)$ indicate that the DCM is shallower than the PNM by a factor of $\sim 0.62$ and the nitracline is deeper than the PNM by a factor of $\sim 1.2$ 
was described earlier in the tropical and equatorial Atlantic (Collos \& Slawyk 1983). This phenomenon suggests that at that time the rate of ammonium oxidation was much higher than the rate of vertical transport (turbulence and sinking) of POM and ammonia. Alternatively, the rate of ammonification was much slower than the rate of vertical transport and the AM might have migrated upwards and been consumed by phytoplankton. If the former process had occurred then the removal rate can be expressed using information from the sampling resolution of the water column profiles in this study $( \pm 5 \mathrm{~m})$. The disappearance of the AM in the summer means that ammonium is completely oxidized to nitrite within a vertical interval of $\sim 10 \mathrm{~m}$, or:

$$
\sqrt{\left(D_{\mathrm{T}} K^{-1}\right)}+S \times K^{-1} \leq 10
$$

where $K$ is the combined 'pseudo' rate constant for POM and ammonium oxidation $\left(\mathrm{d}^{-1}\right)$. This may be the reason that when the AM disappears, the magnitude of the PNM increases slightly compared to the typical summer concentrations.

In summary, we suggest that transport-reaction mechanisms determine the vertical separation between the peaks of the $\mathrm{N}$-species as follows: the faster the reaction rate and the slower the vertical transport, the smaller the vertical separation between the peaks.

\section{An estimate of the ratios between the rate constants of the $\mathbf{N}$ transformation processes}

Assuming that the above explanation for the water column vertical order of the $\mathrm{N}$-species is valid, then nitrite is an intermediate $\mathrm{N}$ product in a cascade of POM degradation processes. We describe this cascade by a simple 1D mass-balance model containing 4 nitrogen boxes (Fig. 8). The 4 vertically interconnected N reservoirs from the DCM at the top down to the nitracline are: phytoplankton $\mathrm{N}$, ammonium, nitrite and nitrate. The system is assumed to be at steady state; hence, all 4 reservoirs operate within a closed system (inputs into the system are balanced by the outputs). The rate of change of $\mathrm{N}$ in each reservoir is described by an equation with one input and one output 1st order kinetic transfer functions. For the purpose of simplicity we neglected direct consumption of ammonium by phytoplankton, any new external inputs below the DCM, and assumed that the downward transport is identical for all $\mathrm{N}$-species. Hence the vertical distribution of the $\mathrm{N}$ reservoirs is

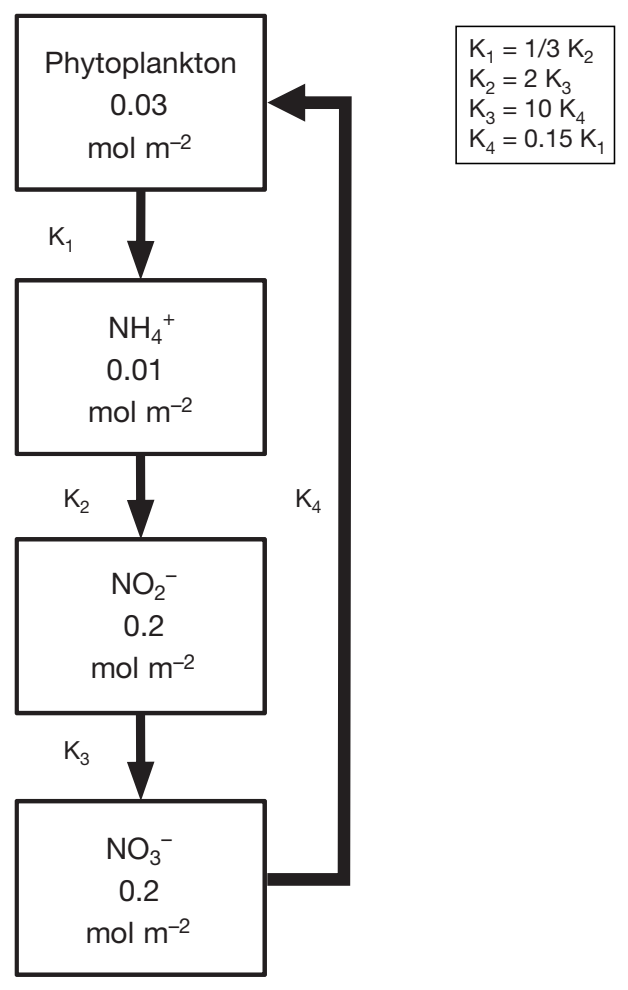

Fig. 8. A simple box model describing the fluxes between 4 interconnected $\mathrm{N}$ reservoirs: phytoplankton, ammonium $\left(\mathrm{NH}_{4}{ }^{+}\right)$, nitrite $\left(\mathrm{NO}_{2}{ }^{-}\right)$and nitrate $\left(\mathrm{NO}_{3}{ }^{-}\right)$. The boxes represent the averaged summer $\mathrm{N}$ inventories $\left(\mathrm{mol} \mathrm{m}^{-2}\right)$ in these reservoirs within the photic zone $(0-100 \mathrm{~m})$ that were calculated from the actual concentration data (Figs. S1 \& S2 in Supplement 3). The various reservoirs (boxes) are ordered vertically according to their water column summer distribution. The rate of change of $\mathrm{N}$ in each reservoir is described by a linear differential equation (1st order kinetic) containing input and output terms (Eqs. 5 to 8 ) and the system is assumed to be at steady state (Eq. 9). The ratios between the various rate constants are given in the box at the upper right corner (see 'Discussion-An estimate of the ratios between

the rate constants of the $\mathrm{N}$ transformation processes')

correlated with the time succession in the closed system experiments:

$$
\begin{aligned}
& \frac{\mathrm{dN}_{\text {phyt }}}{\mathrm{d} t}=\mathrm{K}_{\mathrm{NO}_{\overline{3}}-\text { phyt }} \mathrm{NO}_{3}^{-}-\mathrm{K}_{\text {phyt-NH}}{ }_{4} \mathrm{~N}_{\text {phyt }} \\
& \frac{\mathrm{dNH}_{4}^{+}}{\mathrm{d} t}=\mathrm{K}_{\text {phyt-NH}}^{+} \mathrm{N}_{\text {phyt }}-\mathrm{K}_{\text {phyt-NO}} \mathrm{NH}_{4}^{+} \\
& \frac{\mathrm{dNO}_{2}^{-}}{\mathrm{d} t}=\mathrm{K}_{\mathrm{NH}_{4}^{+}-\mathrm{NO}_{2}^{-}} \mathrm{NH}_{4}^{+}-\mathrm{K}_{\mathrm{NO}_{2}^{-}-\mathrm{NO}_{3}^{-}} \mathrm{NO}_{2}^{-} \\
& \frac{\mathrm{dNO}_{3}^{-}}{\mathrm{d} t}=\mathrm{K}_{\mathrm{NO}_{\overline{2}}-\mathrm{NO}_{\overline{3}}^{-}} \mathrm{NO}_{2}^{-}-\mathrm{K}_{\mathrm{NO}_{\overline{3}}-\mathrm{phyt}} \mathrm{NO}_{3}^{-}
\end{aligned}
$$

where $\mathrm{N}_{\text {phyt }}, \mathrm{NH}_{4}^{+}, \mathrm{NO}_{2}^{-}$and $\mathrm{NO}_{3}^{-}$are the total $\mathrm{N}$ (per unit area) stored in phytoplankton, ammonium, nitrite and nitrate, respectively, and $\mathrm{K}_{\mathrm{NO}_{3}^{-}-\text {phyt }}$ 


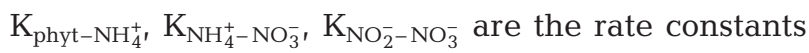
(per unit time) for nitrate assimilation, net phytoplankton ammonification (e.g. production minus re-assimilation by phytoplankton which cannot be separated using our measurements), ammonium oxidation, and nitrite oxidation, respectively. At steady state all $\mathrm{N}$ transformation rates are equal, meaning that:

$$
\begin{aligned}
& \mathrm{K}_{\mathrm{NO}_{3}^{-}-\text {phyt }} \mathrm{NO}_{3}^{-}= \mathrm{K}_{\text {phyt-NH}} \mathrm{N}_{\text {phyt }}= \\
& \mathrm{K}_{\mathrm{NH}_{4}^{+}-\mathrm{NO}_{\overline{2}}} \mathrm{NH}_{4}^{+}=\mathrm{K}_{\mathrm{NO}_{\overline{2}}-\mathrm{NO}_{3}^{-}} \mathrm{NO}_{2}^{-}
\end{aligned}
$$

Thus, the ratios between water column inventories of the $\mathrm{N}$ reservoirs (Fig. 4) yield the ratios between the rate constants of the various processes:

$$
\begin{aligned}
& \frac{\mathrm{K}_{\mathrm{NO}_{3}^{-}-\text {phyt }}}{\mathrm{K}_{\text {phyt-NH}}}=\frac{\mathrm{N}_{\text {phyt }}}{\mathrm{NO}_{3}^{-}} ; \quad \frac{\mathrm{K}_{\text {phyt- } \mathrm{NH}_{4}^{+}}}{\mathrm{K}_{\mathrm{NH}_{4}^{+}-\mathrm{NO}_{2}^{-}}}=\frac{\mathrm{NH}_{4}^{+}}{\mathrm{N}_{\text {phyt }}} ; \\
& \frac{\mathrm{K}_{\mathrm{NH}_{4}^{+}-\mathrm{NO}_{2}^{-}}}{\mathrm{K}_{\mathrm{NO}_{\overline{2}}-\mathrm{NO}_{\overline{3}}^{-}}}=\frac{\mathrm{NO}_{2}^{-}}{\mathrm{NH}_{4}^{+}} ; \quad \frac{\mathrm{K}_{\mathrm{NO}_{\overline{2}}-\mathrm{NO}_{\overline{3}}}}{\mathrm{~K}_{\mathrm{NO}_{\overline{3}}-\text { phyt }}}=\frac{\mathrm{NO}_{3}^{-}}{\mathrm{NO}_{2}^{-}}
\end{aligned}
$$

Substituting the values for the different $\mathrm{N}$ reservoirs into Eq. (10) yields the rate constant ratios of

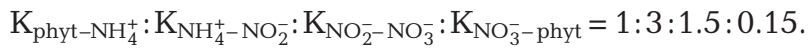
This indicates that the rate constant of ammonium oxidation is the largest rate constant in this sequence of $\mathrm{N}$ transformations. The constant of ammonium oxidation is 20 times larger than the rate constant of nitrate assimilation ('new' production) and 2 times larger than the rate constant of nitrite oxidation. The large rate constant of ammonium explains the extremely fast changes in ammonium concentrations in the water column (Fig. 1). We note that this model assumes that the major sink for ammonium is microbial oxidation, and this may be an oversimplification if phytoplankton plays a bigger role in consuming ammonium as an $\mathrm{N}$ source below the DCM. The decay curve of the DCM strongly suggests that ammonification of dead phytoplankton cells is the major source of ammonium giving rise to the $\mathrm{AM}$; however, more work is needed to determine the role of phytoplankton, if any, in ammonium uptake.

The rate constant $\left(\mathrm{d}^{-1}\right)$ ratios estimated here from the GOA profiles (Fig. 1) are within the range of the nitrogen transformation rate $\left(\mathrm{mol} \mathrm{l}^{-1} \mathrm{~d}^{-1}\right)$ ratios measured in laboratory bioassays on waters from marine environments with similar $\mathrm{N}$-species inventories (Bianchi et al. 1999, Clark et al. 2008). Although these studies report $\mathrm{N}$ transformation rates, e.g. the

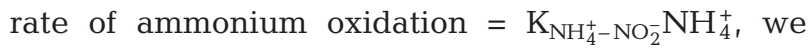
can compare the ratios of the reactions rates to the

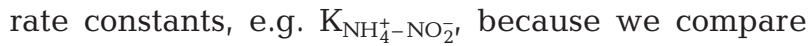
marine environments with similar $\mathrm{N}$ inventories (reservoirs). This comparison is valid as long as the rate of ammonium oxidation is far from saturation, which is a reasonable assumption at the relatively low ammonium concentrations in these waters. For example, Clark et al. (2008) reported ammonium oxidation rates of 1 to $10 \mathrm{nmol} \mathrm{l}^{-1} \mathrm{~d}^{-1}$ and nitrite oxidation rates of 1 to $30 \mathrm{~mol} \mathrm{l}^{-1} \mathrm{~d}^{-1}$ for the Atlantic Gyres. The initial concentrations of ammonium and nitrite reported in their study were 20 to $100 \mathrm{nmol}^{-1}$ and ca. $5 \mu \mathrm{M}$ respectively. Using these values the calculated rate constants in their study were $\mathrm{K}_{\mathrm{NH}_{4}^{+}-\mathrm{NO}_{2}^{-}}$of 2 to $20 \mathrm{~d}^{-1}$ and $\mathrm{K}_{\mathrm{NO}_{2}^{-} \mathrm{NO}_{3}^{-}}$of 0.2 to $5 \mathrm{~d}^{-1}$, suggesting that the rate constant of ammonium oxidation is between 4 and 10 times larger than the rate constant of nitrite oxidation. As mentioned above, this calculation assumes that the concentration of ammonium is low enough that ammonium oxidation rates are not saturated.

\section{Direct nitrite excretion by phytoplankton during winter mixing}

Our observations during winter mixing support previous reports from the GOA (Al-Qutob et al. 2002 Mackey et al. 2011) suggesting that direct excretion of nitrite by phytoplankton is the main mechanism producing nitrite in this season. The 3 main lines of evidence for nitrite excretion by phytoplankton during mixing are (1) nitrite accumulates simultaneously with the increase in chl a inventory (Figs. 1a,f \& 4), (2) the depth profiles of ammonium and nitrite in the mixing period are not coupled, as would be expected if nitrite was the product of microbial oxidation of ammonium (Fig. 1a,f), and (3) the nitrite and chlorophyll water column inventories increase while nitrate inventory decrease (Fig. 5), indicating that phytoplankton excrete nitrite during the assimilation (reduction) of nitrate.

This study demonstrates that both mechanisms suggested for nitrite accumulation, phytoplankton nitrite excretion and nitrification, can co-exist in the same environment. We suggest that the dominance of either of the mechanisms depends on seasonal water column dynamics.

\section{CONCLUSIONS}

In this study we provide field evidence for nitrification as the prime mechanism for producing the prominent PNM near the base of the photic zone during summer stratification. The evidence in sup- 
port of nitrification during summer includes the following.

(1) The vertical order of the $\mathrm{N}$-species distribution according to their oxidation state from the most reduced (organic-N) to the most oxidized (nitrate) implies that a series of oxidation processes are shaping the profiles, rather than reduction processes controlled by phytoplankton.

(2) A development of nitrite and ammonium peaks simultaneously with the decay of chl $a$ at the onset and during stratification link the formation of the PNM with oxidation/decomposition reactions.

(3) Diurnally steady location, shape and magnitude of the PNM at the base of the photic zone indicates that low light is essential for producing the PNM but it is not affected by oscillations in the light regime.

(4) A 1D transport-reaction model explains the vertical order of water column $\mathrm{N}$-species in general and specifically the formation of the PNM. The model includes terms for particles sinking, ammonification, nitrification and turbulent transport of solutes. The transport-reaction of the different $\mathrm{N}$-species determines the vertical separation between the peaks of these species.

(5) A linear box model for the different $\mathrm{N}$ reservoirs in the water column yields relative rate constants for ammonification, ammonium oxidation, nitrite oxidation and nitrate assimilation to be $\mathrm{K}_{\text {phyt- } \mathrm{NO}_{4}^{+} \text {: }}$

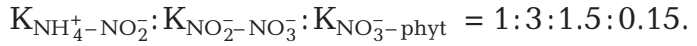

The main process responsible for nitrite accumulation in the water column during winter mixing is excretion of nitrite by phytoplankton, as suggested by previous studies.

We propose that both nitrite producing mechanisms, nitrification and excretion by phytoplankton, co-exist spatially but operate in different seasons; however the dominating process is determined mainly by water column stability.

Acknowledgements. Funds for this study were provided by the BMBF (Germany) Red Sea Program (B.L.), The MERCUSAID (The U.S. Agency for International Development), Peace-Park Program (B.L.) and The Niedersachsen State Fund to the Hebrew University (A.F.P.). Part of the data was collected during the cruises of the National Monitoring Program (NMP) of the Gulf of Aqaba (The Israeli Ministry of Environmental Protection). The high temporal resolution data of spring 2008 was collected during the NATO 'Science for Peace' project (Sfp 982161 to A.P. and A.F.P.) and the 8th International Workshop of the Group for Aquatic Primary Productivity (GAP) and the Batsheva de Rothschild Seminar on Gross and Net Primary Productivity held at the Interuniversity Institute for Marine Sciences, Eilat, Israel (April 2008). Other funds were provided to the authors by The Moshe Shilo Center for Marine Biogeochemistry (B.L., Y.S.), Batsheva de Rothschild Foundation and Bar Ilan University
(N.S., D.I.). We thank the directors and staff of the Interuniversity Institute for Marine Sciences, Eilat, NMP for providing equipment, research vessel and logistic support, and the skippers and staff of the vessels 'Sea Surveyor' and 'Queen of Sheba' for their on-board assistance. K.R.M.M. was supported by a Department of Energy (DOE) Global Change Education Program Fellowship. This paper is a part of the PhD study of the senior author (E.M.).

\section{LITERATURE CITED}

Adornato LR, Kaltenbacher EA, Villareal TA, Byrne RH (2005) Continuous in situ determinations of nitrite at nanomolar concentrations. Deep-Sea Res I 52:543-551

Al-Qutob M, Häse C, Tilzer M, Lazar B (2002) Phytoplankton drives nitrite dynamics in the Gulf of Aqaba, Red Sea. Mar Ecol Prog Ser 239:233-239

Badran MI, Rasheed M, Manasrah R, Al-Najjar T (2005) Nutrient flux fuels the summer primary productivity in the oligotrophic waters of the Gulf of Aqaba, Red Sea. Oceanologia 47:47-60

Bianchi MF, Feliatra, Lefevre D (1999) Regulation of nitrification in the land-ocean contact area of the Rhone River plume (NW Mediterranean). Aquat Microb Ecol 18: 301-312

Blanchot J, André JM, Navarette C, Neveux J (1997) Picophytoplankton dynamics in the equatorial Pacific: diel cycling from flow-cytometer observations. CR Acad Sci Ser III 320:925-931

Brandhorst W (1959) Nitrification and denitrification in the Eastern Tropical North Pacific. J Con Int Explor Mer 25: 3-20

- Brzezinski M (1988) Vertical distribution of ammonium in stratified oligotrophic waters. Limnol Oceanogr 33: 1176-1182

> Chen Y, Mills S, Street J, Golan D, Post A, Jacobson M, Pay$\tan A$ (2007) Estimates of atmospheric dry deposition and associated input of nutrients to Gulf of Aqaba seawater. J Geophys Res 112:D04309 doi:10.1029/2006JD007858

Clark DR, Rees AP, Joint I (2008) Ammonium regeneration and nitrification rates in the oligotrophic Atlantic Ocean: implications for new production estimates. Limnol Oceanogr 53:52-62

> Collos Y (1998) Nitrate uptake, nitrite release and uptake, and new production estimates. Mar Ecol Prog Ser 171:293-301

Collos Y, Slawyk G (1983) Ammonium and nitrate in the tropical and equatorial Atlantic-relations with the primary nitrite maximum. Mar Biol Lett 4:295-308

Dore JE, Karl DM (1996a) Nitrite distributions and dynamics at station ALOHA. Deep-Sea Res II 43:385-402

> Dore JE, Karl DM (1996b) Nitrification in the euphotic zone as a source for nitrite, nitrate, and nitrous oxide at Station ALOHA. Limnol Oceanogr 41:1619-1628

> Foster RA, Paytan A, Zehr JP (2009) Seasonality of $\mathrm{N}_{2}$ fixation and nifH gene diversity in the Gulf of Aqaba (Red Sea). Limnol Oceanogr 54:219-233

Francis CA, Roberts KJ, Beman JM, Santoro AE, Oakley BB (2005) Ubiquity and diversity of ammonia-oxidizing archaea in water columns and sediments of the ocean. Proc Natl Acad Sci USA 102:14683-14688.

French DP, Furnas MJ, Smayda TJ (1983) Diel changes in nitrite concentration in the chlorophyll maximum in the Gulf of Mexico. Deep-Sea Res I 30:707-721

Genin A, Lazar B, Brenner S (1995) Vertical mixing and 
coral death in the Red Sea following the eruption of Mount Pinatubo. Nature 377:507-510

Grasshoff K, Kremling K, Ehrhardt M (1999) Methods of seawater analysis, 3rd edn. Wiley-VCH, New York, NY

$>$ Guerrero MA, Jones RD (1996a) Photoinhibition of marine nitrifying bacteria. I. Wavelength-dependent response. Mar Ecol Prog Ser 141:183-192

> Guerrero MA, Jones RD (1996b) Photoinhibition of marine nitrifying bacteria. II. Dark recovery after monochromatic or polychromatic irradiation. Mar Ecol Prog Ser 141:193-198

Holmes RM, Aminot A, Kérouel R, Hooker BA, Peterson BJ (1999) A simple and precise method for measuring ammonium in marine and freshwater ecosystems. Can J Fish Aquat Sci 56:1801-1808

Hooper AB, Terry KR (1974) Photoinactivation of ammonia oxidation in Nitrosomonas. J Bacteriol 119:899-906

Horrigan SG, Carlucci AF, Williams PM (1981) Light inhibition of nitrification in sea-surface films. J Mar Res 39: $557-565$

Iluz D (1998) The light field, phytoplankton pigmentation and productivity in the Gulf of Elat. PhD dissertation, Bar-Ilan University, Ramat-Gan

Johnson M, Sanders R, Avgoustidi V, Lucas M and others (2007) Ammonium accumulation during a silicate-limited diatom bloom indicates the potential for ammonia emission events. Mar Chem 106:63-75

Kiefer DA, Olson DJ, Holm-Hansen O (1976) Another look at the nitrite and chlorophyll maxima in the central North Pacific. Deep-Sea Res 23:1199-1208

Lazar B, Erez J, Silverman J, Rivlin T and others (2008) Recent environmental changes in the chemical-biological oceanography of the Gulf of Aqaba (Eilat). In: Por DF (ed) Aqaba-Eilat, the improbable gulf: environment, biodiversity and preservation. Magnes Press, Jerusalem, p 299-321

Le Bouteiller A, Herbland A (1982) Diel variation of chlorophyll $a$ as evidenced from a 13-day station in the Equatorial Atlantic Ocean. Oceanol Acta 5:433-441

Libes S (1992) An introduction to marine biogeochemistry, 1st edn. John Wiley \& Sons, New York, NY

Lindell D, Post AF (1995) Ultraphytoplankton succession is triggered by deep winter mixing in the Gulf of Aqaba (Eilat), Red Sea. Limnol Oceanogr 40:1130-1141

Lomas MW, Lipschultz F (2006) Forming the primary nitrite maximum: nitrifiers or phytoplankton? Limnol Oceanogr 51:2453-2467

Mackey KRM, Labiosa RG, Calhoun M, Street JH, Post AF, Paytan A (2007) Phosphorus availability, phytoplankton community dynamics, and taxon-specific phosphorus status in the Gulf of Aqaba, Red Sea. Limnol Oceanogr 52:873-885

Mackey KRM, Bristow L, Parks DR, Altabet MA, Post AF, Paytan A (2011) The influence of light on nitrogen

Editorial responsibility: Ronald Kiene,

Mobile, Alabama, USA cycling and the primary nitrite maximum in a seasonally stratified sea. Prog Oceanogr 91:545-560

Mordy CW, Eisner LB, Proctor P, Stabeno P (2010) Temporary uncoupling of the marine nitrogen cycle: accumulation of nitrite on the Bering Sea shelf. Mar Chem 121: $157-166$

Olson R (1981) Differential photoinhibition of marine nitrifying bacteria: a possible mechanism for the formation of the primary nitrite maximum. J Mar Res 39:227-238

Parsons TR, Maita Y, Lalli CM (1984) A manual in chemical and biological methods for seawater analysis. Pergamon Press, Oxford

Paytan A, Mackey KRM, Chen Y, Lima ID and others (2009) Toxicity of atmospheric aerosols on marine phytoplankton. Proc Natl Acad Sci USA 106:4601-4605

Post AF, Dedej Z, Gottlieb R, Li H and others (2002) Spatial and temporal distribution of Trichodesmium spp. in the stratified Gulf of Aqaba, Red Sea. Mar Ecol Prog Ser 239: $241-250$

> Saino T, Otobe H, Wada E, Hattori A (1983) Subsurface ammonium maximum in the northern North Pacific and the Bering Sea in summer. Deep-Sea Res 30:1157-1171

> Stambler N (2006) Light and picophytoplankton in the Gulf of Eilat (Aqaba). J Geophys Res 111:C11009, doi: 10.1029/2005JC003373

Sutka RL, Ostrom NE, Ostrom PH, Phanikumar MS (2004) Stable nitrogen isotope dynamics of dissolved nitrate in a transect from the North Pacific Subtropical Gyre to the Eastern Tropical North Pacific. Geochim Cosmochim Acta 68:517-527

Vaulot D, Marie D (1999) Diel variability of photosynthetic picoplankton in the equatorial Pacific. J Geophys Res 104:3239-3310

Wada E, Hattori A (1971) Nitrite metabolism in euphotic layer of the central North Pacific Ocean. Limnol Oceanogr 16:766-772

Wankel SD, Chen Y, Kendall C, Post AF, Paytan A (2010) Sources of aerosol nitrate to the Gulf of Aqaba: evidence from $\delta^{15} \mathrm{~N}$ and $\delta^{18} \mathrm{O}$ of nitrate and trace metal chemistry. Mar Chem 120:90-99

Ward BB (2008) Nitrification in marine systems. In: Capone DG, Bronk DA, Mulholland MR, Carpenter EJ (eds) Nitrogen in the marine environment, 2nd edn. Academic Press, Burlington, MA, p 199-248

> Ward BB, Zafiriou OC (1988) Nitrification and nitric oxide in the oxygen minimum of the eastern tropical North Pacific. Deep-Sea Res A 35:1127-1142

> Wolf-Vecht A, Paldor N, Brenner S (1992) Hydrographic indications of advection/convection effects in the Gulf of Elat. Deep-Sea Res I 39:1393-1401

> Woodward EMS, Rees AP (2001) Nutrient distributions in an anticyclonic eddy in the northeast Atlantic Ocean, with reference to nanomolar ammonium concentrations. Deep-Sea Res II 48:775-793

Submitted: February 24, 2011; Accepted: November 22, 2011 Proofs received from author(s): April 21, 2012 